\title{
FAKTOR-FAKTOR YANG MEMPENGARUHI KEPATUHAN PERAWAT DALAM MELAKUKAN HAND HYGIENE FIVE MOMENTS DI RS. HERMINA JATINEGARA
}

\author{
Ria Anugrahwati ${ }^{1}$,Nuraini Hakim ${ }^{2}$ \\ 3. Dosen Akademi Keperawatan Manggala Husada \\ 4. Dosen Akademi Keperawatan Manggala Husada \\ E-mail: riaanugrahwatirusdin@gmail.com
}

\begin{abstract}
Abstrak
Keperawatan merupakan profesi yang membantu dan memberikan pelayanan yang berkontribusi pada kesehatan dan kesejahteraan individu. Dimana tugas utama perawat memberikan asuhan keperawatan pada klien, mematuhi tugas dan etika yang telah ditentukan diantaranya hand hygiene five moments, agar pasien dan perawat terhindar dari kuman yang dapat memberikan infeksi nosokomial. Penelitian ini bertujuan untuk mengidentifikasi faktorfaktor yang mempengaruhi kepatuhan perawat dalam melakukan hand hygiene five moments five moments. Penelitian ini menggunakan desain survey cross sectional study pada 80 responden perawat. Hasil penelitian menunjukkan karakteristik dari 80 responden sebagian besar $(75,0 \%)$ berjenis kelamin perempuan. Sebagian besar $(75,0 \%)$ responden berusia lebih dari 30 tahun. Dari segi pendidikan, sebagian besar $(81,3 \%)$ diploma keperawatan. Dan lama kerja Dan dari segi lama kerja 11-20 tahun sebagian besar (73,8\%).Terdapat hubungan yang bermakna antara usia, jenis kelamin, lama kerja, pengetahuan, ketersediaan fasilitas, aturan dan lingkungan sosial rumah sakit dengan kepatuhan perawat dengan melakukan hand hygiene five moments five moments di Rs. Hermina Jatinegara. Rekomendasi dari penelitian ini adalahPerawat yang belum patuh melakukan hand hygiene five moments agar dapat meningkatkan kinerja perawat dalam pelaksanaan hand hygiene five moments agar dapat mengurangi angka kejadian infeksi nosokomial dengan cara mengadakan review ulang kepada semua petugas kesehatan tentang langkah cuci tangan yang baik dan benar.
\end{abstract}

Kata kunci: kepatuhan perawat, hand hygiene five moments

\begin{abstract}
Nursing is a profession that helps and provides services that contribute to the health and wellbeing of individuals. Where the main task of nurses is to provide nursing care to clients, obey their assigned duties and ethics, including hand hygiene five moments, so patients and nurses avoid germs that can provide nosocomial infections. This study aims to identify factors that influence nurse compliance in carrying out hand hygiene five moments five moments. This study used a cross sectional survey design study on 80 nurse respondents. The results of the study showed that the characteristics of 80 respondents were mostly (75.0\%) female. Most (75.0\%) respondents are over 30 years old. In terms of education, most $(81.3 \%)$ nursing diplomas. And the length of work and in terms of working duration of 11-20 years are mostly (73.8\%). There is a significant relationship between age, gender, length of work, knowledge, availability of facilities, rules and hospital social environment with nurse compliance with doing hand hygiene five moments five moments in Rs. Hermina Jatinegara. Recommendations from this study are Nurses who have not adhered to hand hygiene five moments in order to improve nurses' performance in the implementation of hand hygiene five moments in order to reduce the incidence of nosocomial infections by reviewing all health workers about the steps of good and correct hand washing.
\end{abstract}

Keywords: compliance of nurses, hand hygiene five moments 


\section{Pendahuluan}

Keperawatan merupakan profesi yang membantu dan memberikan pelayanan yang berkonstribusi pada kesehatan dan kesejahteraan individu. Keperawatan juga diartikan sebagai konsekuensi penting bagi individu yang menerima pelayanan, profesi ini memenuhi kebutuhan yang tidak dapat dipenuhi oleh seseorang, keluarga atau kelompok di komunitas. (Committee on Education American Nurses Association (ANA), 1965).

WHO Expert Committee on Nursing dalam Aditama (2000) mengatakan bahwa, pelayanan keperawatan adalah gabungan dari ilmu kesehatan dan seni melayani/memberi asuhan (care), suatu gabungan humanistik dari ilmu pengetahuan, filosofi keperawatan, kegiatan klinik, komunikasi dan ilmu sosial.

Keperawatan merupakan suatu bentuk pelayanan profesional yang merupakan bagian integral dari pelayanan kesehatan berdasarkan ilmu dan kiat keperawatan, berbentuk pelayanan biopsikososial dan spiritual yang komprehensif, ditujukan kepada individu, keluarga dan masyarakat baik sakit maupun sehat yang mencakup seluruh aspek kehidupan manusia. (Lokakarya Nasional, 1983).
Tugas utama perawat adalah memberikan asuhan keperawatan pada klien. Fokus orientasi ini telah memberi asuhan keperawatan pada klien. Fokus orientasi ini telah memberi implikasi yang sangat besar. Perawat yang berorientasi untuk memberi asuhan keperawatan kepada klien. Selain hal tersebut, seorang perawat harus mematuhi tugas dan etika keparawatan yang telah ditentukan, diantaranya "hand hygiene five moments five moments",. Hand hygiene five moments adalah istilah yang digunakan untuk mencuci tangan menggunakan antiseptik sebelum melakukan berbagai aktivitas, khusunya pada pada five moments penting yaitu : sebelum kontak dengan pasien, sebelum tindakan aseptic, setelah berisiko kontak dengan cairan tubuh, setelah kontak dengan pasien, dan setelah berada di lingkungan pasien. (WHO, 2009)

Sebagaimana Kebijakan Kementerian Kesehatan bahwa rumah sakit di Indonesia wajib mengikuti standar akreditasi nasional empat pelayanan dasar, dimana patient safety merupakan standar pelayanan yang menjadi target utama, termasuk di dalamnya tentang pencegahan dan pengendalian infeksi di rumah sakit. 
Salah satu komponen penting sebagai indikator mutu pelayanan di rumah sakit adalah kejadian infeksi dimana dapat dicegah melalui penerapan hand hygiene five moments.

Perawat yang merupakan salah satu petugas kesehatan memiliki resiko tinggi menularkan pathogen melalui tangan, karena perawat memiliki peluang yang besar berada pada five moment penting tersebut, sehingga kepatuhan mencuci tangan perawat hendaknya ditingkatkan. Tujuan mencuci tangan sebelum kontak dengan pasien yaitu untuk menghindarkan pasien dari paparan kotoran dan kuman yang dibawa oleh tenaga kesehatan lain dari pasien lain sehingga pasien dapat terhindar dari kuman yang dibawa oleh tenaga kesehatan lain dari kuman yang dapat memperparah penyakit yang diderita. Mencuci tangan sesudah kontak dengan pasien bertujuan untuk membersihkan tangan perawat atau tenaga kesehatan lain dari kuman yang didapat ketika kontak dengan pasien ataupun dengan lingkungan disekitar pasien yang beresiko terpajan kuman. Hal ini sangat berguna bagi perawat agar tidak terkena infeksi dan mencegah penularan serta penyebaran kuman kepada orang lain. (Kepmenkes RI,2009)

Terjadinya infeksi nosokomial dipengaruhi oleh banyak faktor, salah satunya faktor ialah ketidak patuhan petugas kesehatan dalam tindakan penanganan pasien, petugas kesehatan tidak melakukan cuci tangan dengan benar sebelum dan sesudah tindakan penanganan pasien. Pada perkembangannya infeksi tersebut diistilahkan Hospital Associated Infections ( HAIs).

\section{Hospital Associated Infections ( HAIs}

) merupakan infeksi yang didapatkan pasien selama menjalani perawatan di rumah sakit ( RS). HAIs masih menjadi permasalahan di seluruh dunia. Kerugian disebabkan oleh HAIs memutuskan upaya untuk menekan angka kejadian tersebut dengan cara menggunakan alat pelindung diri (sarung tangan, masker dll), peralatan perawatan pasien yang harus steril, pengendalian lingkungan serta tindakanterpenting dalam mengurangi HAIs yaitu dengan menjaga kebersihan tangan atau hand hyigiene. Hand hyigiene wajib diterapkan dan dipatuhi oleh tenaga kesehatan terlebih perawat dikarenakan $80 \%$ infeksi disebarkan melalui tangan.

Beberapa pathogen penyebab HAIs memiliki frekuensi yang cukup tinggi 
ditangan, seperti : Staphylococcus aureus yang merupakan penyebab utama dari infeksi luka paska operasi dan pneumonia memiliki frekuensi sekitar $10-78 \%$ ditangan, pseudomonas spp merupakan patogen penyebab infeksi nafas bawah memiliki frekuensi sekitar $1-25 \%$ ditangan, jamur candida $s p$ sekitar 23 - $81 \%$ dan dapat bertahan selama satu jam di tangan.

Di Indonesia, angka kejadian penyakit infeksi bakteri pada tingkat layanan rawat inap tingkat lanjut sampai dengan desember 2014 mencapai 148.703 kasus (Kemenkes RI 2015). Di Jawa Tengah angka infeksi nosokomial mengalami peningkatan dari tahun 2010-2011 dari 0,37\% menjadi 1,48\% kasus (Nugraheni et al 2012)

Berdasarkan uraian tersebut, penulis terdorong untuk melakukan penelitian terhadap faktor-faktor yang mempengaruhi kepatuhan perawat dalam melakukan hand hygiene five moments five moments di Rs. Hermina Jatinegara. Sebagaimana observasi awal penulis di Rs. Hermina Jatinegara, hand hygiene five moments five moments telah dipatuhi dengan baik oleh perawat, sehingga penting untuk diteliti faktor-faktor yang mendorong perawat di dalam mematuhi aturan tersebut.

\section{Metodologi}

Penelitian ini merupakan penelitian deskriptif yaitu metode penelitian yang dilakukan dengan tujuan untuk membuat gambaran atau deskriptif tentang suatu keadaan secara objektif (Notoatmodjo, 2012). Desain penelitian ini menggunakan pendekatan Cross Sectional yang bertujuan mengetahui hubungan variabel bebas yaitu pendidikan dan pengetahuan, ketersediaan fasilitas, aturan dan lingkungan sosial rumah sakit. Variabel terikat yaitu kepatuhan perawat dan variabel kontrol adalah karakteristik individu perawat yang meliputi: jenis kelamin dan usia. Total populasi berjumlah 202 orang, sedangkan sampel yang digunakan hanya 80 orang. Tempat penelitian dilakukan di Rs Hermina Jatinegara Jakarta.

\section{Hasil Penelitian}

\section{Karakteristik responden}

Karakteristik responden meliputi Usia, jenis kelamin, pendidikan, lama kerja, pengetahuan, ketersediaan fasilitas, aturan lingkungan sosial rumah sakit dan kepatuhan 
Tabel 1.

Distribusi responden berdasarkan usia, jenis kelamin, pendidikan, lama kerja di Rs. Hermina Jatinegara Tahun 2018

$$
(n=80)
$$

\section{Variabel}

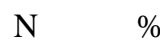

8. Usia
d. 20-30 tahun
$20 \quad 25,0$
e. 31-40 tahun

$60 \quad 75,0$

9. Jenis Kelamin

e. Perempuan $\quad 60 \quad 75,0$

$\begin{array}{lll}\text { f. Laki-laki } 20 & 25,0\end{array}$

10. Pendidikan

d. D3

e. S1

11. Lama Kerja

\begin{tabular}{|c|c|}
\hline 1-10 tahun & 21 \\
\hline $11-20$ tahun & 59 \\
\hline
\end{tabular}

Berdasarkan Tabel 1 di atas menunjukkan bahwa dari 80 responden didapatkan Proporsi terbesar berusia > 30 tahun tahun sebanyak responden (75\%), proporsi terbesar pada jenis kelamin perempuan sebanyak 60 responden (75\%). Proporsi terbesar pada pendidikan D3 sebanyak 65 respoden $(81,3 \%)$. Dan proporsi terbesar pada lama kerja 11-20 tahun sebanyak 59 responden $(73,8 \%)$

Faktor-faktor yang mempengaruhi kepatuhan perawat dalam melakukan hand hygiene five moments

Tabel 2

Tabel 2.Distribusi Responden Berdasarkan pengetahuan, ketersediaan fasilitas, aturan dan lingkungan sosial rumah sakit dan kepatuhan di Rs. Hermina Jatinegara Tahun $2018(n=80)$

$\begin{array}{lll}\quad \text { Variabel } & \text { N } & \% \\ \begin{array}{ccc}\text { Pengetahuan } \\ \text { Kurang }\end{array} & 21 & 26,3 \\ \text { Baik } & 59 & 73,8\end{array}$

Ketersediaan fasilitas

$\begin{array}{lll}\text { Kurang } & 21 & 26,3 \\ \text { Baik } & 59 & 73,8\end{array}$

Aturan dan lingkungan

sosial rumah sakit

$\begin{array}{lll}\text { Kurang } & 22 & 27,5 \\ \text { Baik } & 58 & 72,5 \\ \text { patuhan } & & \\ \text { Tidak patuh } & 21 & 26,3 \\ \text { Patuh } & 59 & 73,8\end{array}$

Berdasarkan Tabel 2 di atas menunjukkan bahwa dari 80 responden didapatkan proporsi terbesar pengetahuan baik sebanyak 59 responden $(73,8 \%)$. Proporsi terbesar ketersediaan fasilitas baik sebanyak 59 responden $(73,8 \%)$. Proporsi terbesar aturan dan lingkungan sosial rumah sakit baik sebanyak 58 responden $(72,5 \%)$. Dan proporsi terbesar kepatuhan sebanyak 59 responden $(73,5 \%)$.

Korelasi usia, jenis kelamin, pendidikan, lama kerja, pengetahuan, ketersediaan fasilitas, atur sosial rumah sakitan dan lingkungan dengan Kepatuhan

Tabel 3. Hubungan usia, jenis kelamin, pendidikan, lama kerja, pengetahuan, ketersediaan fasilitas, aturan dan lingkungan sosial rumah sakitdengan kepatuhtan perawat dalam melakukan hand hygiene five moments five momens di Rs. Hermina JatinegaraTahun $2018(\mathrm{n}=80)$ 


\begin{tabular}{|c|c|c|}
\hline Variabel & $\mathrm{R}$ & Pvalue \\
\hline 7. Usia & 12,071 & 0,000 \\
\hline 8. Jenis kelamin & 6,111 & 0,002 \\
\hline 9. Pendidikan & 6,222 & 0,113 \\
\hline 10. Lama kerja & 5,390 & 0,004 \\
\hline 11. Pengetahuan & 5,390 & 0,004 \\
\hline 12. Ketersediaan fasilitas & 5,390 & 0,004 \\
\hline $\begin{array}{l}\text { 13. Aturan dan lingkungan sosial } \\
\text { rumah sakit }\end{array}$ & 4,800 & 0.007 \\
\hline
\end{tabular}

Berdasarkan Tabel 3 diketahui terdapat hubungan antara usia, jenis kelamin, lama kerja, pengetahuan, ketersediaan fasilitas, aturan dan lingkungan sosial dengan kepatuhan perawat dalam melakukan hand hygiene five moments di Rs. Hermina Jatinegara.

\section{Pembahasan}

Hasil penelitian diperoleh bahwa ratarata responden paling banyak yaitu pada usia $>30$ tahun. Tingkat pendidikan perawat diruang rawat Rs. Hermina Jatinegara bervariasi. Pendidikan D3 sebanyak 81,3 \% dan selebihnya S1.

Hasil analisis terhadap pengetahuan responden tentang hand hygiene five moments melalui kuesioner didapatkan bahwa 21 orang responden memiliki pengetahuan yang masih kurang. Hasil analisis hubungan antara kepatuhan melakukan hand hygiene five moments dan tingkat pengetahuan diperoleh ada hubungan yang bermakna antara tingkat pengetahuan dengan kepatuhan perawat melakukan hand hygiene five moments. Banyak faktor yang berhubungan dengan kepatuhan perawat melakukan hand hygiene five moments salah satunya adalah mungkin kurangnya pengetahuan perawat akan pentingnya melakukan hand hygiene five moments dalam mengurangi penyebaran bakteri dan terjadinya kontaminasi pada tangan dan kurang mengerti tentang teknik melakukan hand hygiene five moments yang benar (Pitted \& Boyce, 2001). Hal ini juga dinyatakan oleh WHO (2002) bahwa kurangnya pengetahuan tentang hand hygiene five moments merupakan salah satu hambatan untuk melakukan hand hygiene five moments sesuai rekomendasi. Menurut analisis peneliti dengan pengetahuan yang semakin banyak tentang bahaya infeksi nosokomial membuat perawat patuh melakukan hand hygiene five moments agar pasien tidak mendapat penyakit tambahan.Hasil uji statistik menunjukkan ada hubungan yang signifikan antara ketersediaan fasilitas dengan kepatuhan. Dari hasil kuesioner didapatkan ketersediaan 
fasilitas baik dan membuat perawat patuh melakukan hand hygiene five moments. Hasil penelitian ini sejalan dengan hasil penelitian Pitted (2001) menyatakan bahwa salah satu kedala dalam ketidakpatuhan terhadap hand hygiene five moments adalah sulitnya mengakses tempat cuci tangan atau persediaan alat lainnya yang digunakan untuk melakukan hand hygiene five moments. Kemudian dalam mengakses persediaan alat-alat untuk melakukan hand hygiene five moments, sabun, alcohol adalah sangat penting untuk membuat kepatuhan menjadi optimal sesuai standar. Menurut analisis peneliti, jika fasilitas untuk hand hygiene lengkap serta cairan antiseptik selalu ada di tempat tidur pasien, nurse station dan lorong ruangan rawat membuat perawat akan patuh melakukan hand hygiene five moments.Hasil uji statistik menunjukkan ada hubungan yang signifikan antara aturan dan lingkungan sosial rumah sakit dengan kepatuhan. Dalam hal ini kepatuhan pelaksanaan prosedur tetap adalah untuk selalu memenuhi petunjuk atau peraturan-peraturan dan memahami etika keperawatan di tempat perawat tersebut bekerja. Kepatuhan merupakan modal dasar seseorang berperilaku. Perubahan sikap dan perilaku individu diawali dengan proses patuh, identifikasi dan tahap terakhir berupa internalisasi (Sukron, 2013).

\section{Simpulan}

1. Karakteristik dari 80 responden sebagian besar (75,0\%) berjenis kelamin perempuan. Sebagian besar (75,0\%) responden berusia 30 tahun, sebagian besar $(81,3 \%)$ responden pendidikan D3. Dan dari segi lama kerja sebagian besar (73,8\%) 11-20 tahun.

2. Terdapat hubungan yang bermakna antara usia dengan kepatuhan perawat dalam melakukan hand hygiene five moments $\mathrm{di}$ Rs. Hermina Jatinegara.

3. Terdapat hubungan yang bermakna antara jenis kelamin dengan kepatuhan perawat dalam melakukan hand hygiene five moments di Rs. Hermina Jatinegara.

4. Terdapat hubungan yang bermakna antara lama kerja dengan kepatuhan perawat dalam melakukan hand hygiene five moments di Rs. Hermina Jatinegara.

5. Terdapat hubungan yang bermakna antara pengetahuan dengan kepatuhan perawat dalam melakukan hand hygiene five moments di Rs. Hermina Jatinegara.

6. Terdapat hubungan yang bermakna antara ketersediaan fasilitas dengan kepatuhan perawat dalam melakukan hand hygiene five moments di Rs. Hermina Jatinegara. 
7. Terdapat hubungan yang bermakna antara aturan dan lingkungan sosial dengan kepatuhan perawat dalam melakukan hand hygiene five moments di Rs. Hermina Jatinegara.

\section{Saran}

Hasil penelitian ini dapat digunakan bagi profesi keperawatan untuk menindaklanjuti hasil penelitian ini dengan mengkaji faktorfaktor lainnya, serta membuat pelatihan yang tepat untuk meningkatkan kepatuhan petugas kesehatan khususnya perawat sendiri dalam melakukan hand hygiene five moments.

\section{Daftar Pustaka}

Arikunto, S (2002). Prosedur Pendahuluan Suatu Pendekatan Praktek. Rineka Cipta. Jakarta

Dharma.K.K (2011), Metodologi Penelitian Keperawatan. CV. Trans Info Media : Jakarta

Haryanto (2008). Konsep Dasar Keperawatan Dengan Pemetaan Konsep. Salemba Medika Jakarta

Notoatmojo, S. (2010). Metedologi Penelitian Kesehatan. Jakarta: Rineka Cipta

Mohamad Aris Mahfud (2008). Gambaran Ketaatan Cuci Tangan Perawat Di Rs. Soeradji Tirtonegoro Klaten. Universitas
Gajah Mada Yogyakarta (tidak dipublikasikan)

Mubarak, W.I (2008). Buku Ajar KDM Teori dan Aplikasi Dalam Praktek. EGC. Jakarta

Potter \& Perry (2005). Fundamental Keperawatan. Jakarta : EGC

Proverawati Atikah \& Eni Rahmawati (2012). Perilaku Hidup Bersih dan Sehat. Yogyakarta: Muhamedika

Supratman (2008). Model-model Supervisi Keperawatan Klinik. Diambil pada 20 mei 2018 dari http: www.lib,ui.ac.id/

Syaifudin Abdul Bari (2004). Pandauan Pencegahan Infeksi Untuk Fasilitas Pelayanan Kesehatan Dengan Sumber Daya Terbatas. Jakarta : Yayasan Bina Pustaka Sarwono Prawirohardjo

Yulia. S (2008). Panduan Praktik Keperawatan Kebutuhan Dasar Manusia. Pt. citra Aji Parama, Yogyakarta 